\title{
DETERMINATION OF FREE AMINO ACID CONTENT IN THE SLOVENIAN DRY-CURED HAM »KRAŠKI PRŠUT" AND PRODUCT CHARACTERIZATION
}

\author{
Lucija JANEŠ ${ }^{1}$, Špela VELIKONJA BOLTA ${ }^{2}$, Martin ŠKRLEP ${ }^{2}$, Marjeta ČANDEK-POTOKAR ${ }^{3}$, \\ Maja PREVOLNIK ${ }^{3}$
}

Received January 13, 2012; accepted May 23, 2012.

Delo je prispelo 13. januarja 2012, sprejeto 23. maja 2012.

\begin{abstract}
Determination of free amino acid content in the Slovenian drycured ham »Kraški pršut « and product characterization

The aim of this study was to characterize the chemical profile of dry-cured ham selected and processed in accordance with the Slovenian consortium rules for "Kraški pršut « and to investigate the differences between the Biceps femoris (BF) and the Semimembranosus (SM) muscle. The free amino acid content, moisture, salt, protein, total nitrogen, non-protein nitrogen, proteolysis index, intramuscular fat and dry matter were analysed in 135 samples of dry-cured hams including both muscles. A modified method for sample preparation was developed for determination of free amino acids in dry-cured ham. The method was validated for linearity, limit of detection, limit of quantification, precision and uncertainty. According to the validation parameters the method is appropriate for the determination of free amino acid content in dry-cured ham. Higher content for several free amino acids and total free amino acids were determined in the BF muscle compared to the SM muscle.

Key words: meat products / dry-cured ham / Kraški pršut / chemical composition / free amino acids / methods / postcolumn derivatization / muscles / Biceps femoris / Semimembranosus
\end{abstract}

\section{INTRODUCTION}

Amino acids are essential to life and have many functions in metabolism. One important function is building blocks of proteins which are linear chains of amino acids (Gaull, 1989). During the processing of drycured meat products, e.g. dry-cured ham, meat proteins undergo intensive proteolysis resulting in relatively high amounts of free amino acids (Toldrá and Flores, 1998).
Vsebnost prostih amino kislin v kraškem pršutu in opis izdelka Namen te študije je bil okarakterizirati kemijsko sestavo pršuta, ki je bil izbran in obdelan v skladu s slovenskimi pravili konzorcija za "Kraški pršut « in določiti razlike med Biceps femoris (BF) in Semimembranosus (SM) mišicama. Določili smo vsebnost prostih aminokislin, vlage, soli, beljakovin, skupnega dušika, ne-proteinskega dušika, proteolizni indeks, intramuskularne maščobe in suhe snovi v 135 vzorcih pršuta v obeh mišicah. Modificirali smo pripravo vzorcev za določanje prostih aminokislin v pršut. Metodo smo validirali in določili območje linearnosti, mejo detekcije, mejo kvantifikacije, ponovljivost in obnovljivost. Glede na dobljene rezultate je metoda primerna za določanje prostih aminokislin v pršutu. Višje vsebnosti nekaterih prostih aminokislin in skupnih prostih aminokislin so bile $\mathrm{v}$ mišici BF v primerjavi $\mathrm{z}$ mišico SM.

Ključne besede: mesni izdelki / pršut / Kraški pršut / kemijska sestava / proste aminokisline / metode / post-kolonska derivatizacija / mišice / Biceps femoris / Semimembranosus

Amino acids are beside nucleotides, peptides and inorganic salts important taste compounds in dry-cured meat products (MacLeod, 1986).

The proteolysis begins with the action of calpains which cause only partial proteolysis of cytoskeletal and myofibrillar proteins (Goll et al., 2003) followed by intensive action of cathepsin enzymes able to hydrolyse the majority of muscle proteins. The process of proteolysis is continued by breakdown of peptides as demonstrated by

1 Agricultural Institute of Slovenia, Hacquetova ulica 17, SI-1000 Ljubljana, Slovenia, e-mail: lucija.janes@kis.si

2 Same address as 1

3 Same address as 1 and Faculty of Agriculture and Life Sciences, University of Maribor, Pivola 10, SI-2311 Hoče, Slovenia 
progressive decrease of middle size peptides (molecular weight - MW from $2700 \mathrm{Da}$ to $4500 \mathrm{Da}$ ) and increase of smaller peptides with MW below 1200 Da (RodríguezNuñez et al., 1995). Proteolysis continues with the generation of free amino acids. During the lengthy processing of dry-cured ham amino-peptidases degrade peptides and are responsible for amino acid generation which contributes to texture and flavour development (McDonald and Barrett, 1986). Free amino acids are highly correlated with the development of taste and flavour in dry-cured products (McCain et al., 1968). Sweet taste is related to tryptophane, phenylalanine, histidine, tyrosine, leucine, glycine and alanine; bitter taste with valine, methionine is related to sea flavour, and the presence of glutamic acid is associated with characteristic meaty flavor (Kato et al., 1989).

Representative Slovenian Mediterranean type of dry-cured ham is "Kraški pršut « which is similar to the well known Italian "prosciutto". This type of ham is characterized by dry salting and long maturation period during which characteristic sensory properties are developed due to the enzymatic processes involved (Toldrá, 2002).

Chromatographic procedures related to the analysis of amino acid-containing and amine-containing matrices were classified in three groups, i.e. simultaneous analysis of amino acids and amines from a single run, separate determination of amino acids and amines as different derivatives and quantisation of amines only, following the separation of amino acids from amines. The advantages and drawbacks of all three possibilities were characterized on the basis of recovery, reproducibility values, time and cost phenomena of methods. Separation techniques were high performance liquid chromatography, capillary electrophoresis and ion or ion-exchange chromatography followed by fluorescence, laser-induced fluorescence, coulometric, UV, indirect photometric and integrated pulse amperometric detection (Molnár-Perl, 2003).

The main objective of this work was to determine the free amino acid content and chemical parameters in the Slovenian dry-cured hams "Kraški pršut", to characterize the chemical profile of dry-cured hams and investigate the differences between BF and SM muscles. For the determination of free amino acids in dry-cured hams we used the method for the determination of free amino acids in animal feeding stuffs (ISO 13903, 2005). Due to homogeneity we had to modify the sample preparation, i.e. the weight of sample was enlarged from 5 to $10 \mathrm{~g}$. To improve the extraction and prolong the precipitation of nitrogenous macromolecules the sample homogenates were maintained at $4{ }^{\circ} \mathrm{C}$ for 17 hours prior to the analyses.

\section{MATERIALS AND METHODS}

\subsection{PREPARATION OF SAMPLES}

The material used in the present study comprised 135 Slovenian dry-cured hams »Kraški pršut«. The selection of raw material and green ham evaluation is described by (Škrlep et al., 2010). Hams were selected and processed in accordance with the Slovenian consortium rules for dry ham »Kraški pršut «, i.e. green ham weight above $9.5 \mathrm{~kg}$, subcutaneous fat thickness above $10 \mathrm{~mm}$ and non-PSE (i.e. pale soft and exudative) or non-DFD (i.e. dark, firm and dry) appearance. The processing consisted of two salting phases, resting phase, drying phase and maturation phase, i.e. 60 weeks in total. For the analyses 135 samples of central part of dry-cured BF and 135 samples of SM muscles were taken, vacuum packed and stored at $-20{ }^{\circ} \mathrm{C}$. Prior to the analyses samples of drycured muscles were trimmed of connective and superficial fat tissue, cut in small pieces, frozen in liquid nitrogen, homogenised using a laboratory mill IKA M120 (IKA Werke, Staufen, Germany) and stored in plastic tubes at $-20^{\circ} \mathrm{C}$ until further use.

\subsection{CHEMICAL PARAMETERS}

For the determination of moisture content $5 \mathrm{~g}$ of the sample was mixed with equal amount of quartz sand and dried at $103{ }^{\circ} \mathrm{C}$ for 4 hours to constant mass. The loss of mass was recorded and expressed as a percentage of moisture in the sample (ISO 6496, 1999).

Sodium chloride content was determined as described by (Monin et al., 1997). $1 \mathrm{~g}$ of sample was mixed with $80 \mathrm{~mL}$ deionized water and boiled at $100{ }^{\circ} \mathrm{C}$ for one hour. After cooling, $2 \mathrm{~mL}$ of $15 \%$ potassium ferrocyanide (99.0\% purity, Merck, Darmstadt, Germany) and $2 \mathrm{~mL}$ of $30 \%$ zinc acetate $(99.5 \%$ purity, Merck, Darmstadt, Germany) was added and diluted with deionized water to $100 \mathrm{~mL}$. After filtration, the sodium chloride content was determined by potentiometric titration using 645 MultiDosimat (Metrohm, Herisau, Switzerland).

Total nitrogen content was determined with Kjeldahl method (ISO 5983-2, 2005) using the Kjeltec 2300 nitrogen analyser (Foss Analytical, Hileroed, Denmark).

Preparation of sample for the determination of nonprotein nitrogen was performed as described by (Monin et al., 1997). $2.5 \mathrm{~g}$ of sample was homogenised in $25 \mathrm{~mL}$ of deionized water and centrifuged. Afterwards, $10 \mathrm{~mL}$ of $20 \%$ trichloroacetic acid $(99.5 \%$ purity, Merck, Darmstadt, Germany) was added, stirred well and let to stabilise for $60 \mathrm{~min}$ at room temperature. After centrifugation the supernatant was filtered and $15 \mathrm{~mL}$ of filtrate used for 
determination of nitrogen as described for total nitrogen (ISO 5983-2, 2005).

Intramuscular fat content was determined by standard method (ISO 1443, 1973) using Büchi Extraction System B-811 (Büchi Labortechnik AG, Flawil, Switzerland).

\subsection{DETERMINATION OF FREE AMINO ACID CONTENT}

\subsubsection{CHEMICALS AND REAGENTS}

Deionized water produced by a Milli Q system (Millipore, Bedford, MA, USA), sodium citrate dihydrate, 2,2'-thiodiethanol, sodium hydroxide, 5-sulfosalicylic acid dihydrate (all 99\% purity), phenol (99.5\% purity) and hydrochloric acid (37\% purity) were used (Sigma Aldrich, St. Louis, MO, USA). Standard compounds of amino acids: leucine, tyrosine and phenylalanine (all 98\% purity), aspartic acid, threonine, serine, glutamic acid, proline, glycine, alanine, cystine, valine, methionine, isoleucine, lysine monohydrochloride, histidine monohydrochloride monohydrate, arginine monohydrochloride and internal standard norleucine (all 99\% purity) were used (Sigma Aldrich, St. Louis, MO, USA).

\subsubsection{PREPARATION OF STANDARD SOLU- TIONS AND SAMPLES}

Stock standard solutions of amino acids were prepared by dissolving the weighed solid standard in sodium citrate buffer $(\mathrm{c}=0.2 \mathrm{~mol} / \mathrm{L}, \mathrm{pH} 2.20)$ in the concentration range from 2.5 to $50.0 \mu \mathrm{mol} / \mathrm{mL}$ and further diluted with the same buffer to obtain working solutions of $0.25 \mu \mathrm{mol} / \mathrm{mL}$ for injection into chromatograph equipped with the post column derivatization instrument.
Ten $g$ of the prepared sample was weighed into a conical flask and $100 \mathrm{~mL}$ of extraction mixture $(\mathrm{c}=0.1$ $\mathrm{mol} / \mathrm{L} \mathrm{HCl}$, containing 2\% 2,2'-thiodiethanol) was added. The mixture was shaken for 60 min using a mechanical shaker. When the sediment settled down, $10.0 \mathrm{~mL}$ of the supernatant was transferred into a $100 \mathrm{~mL}$ beaker, 5.0 $\mathrm{mL}$ of $6 \% 5$-sulfosalicylic acid solution was added by stirring and stirred for $5 \mathrm{~min}$ with the magnetic stirrer. The homogenates were maintained at $4{ }^{\circ} \mathrm{C}$ for 17 hours and filtered through Black Ribbon filter (Whatman, Clifton, NJ, USA). $10.0 \mathrm{~mL}$ of filtrate was transferred into $100 \mathrm{~mL}$ beaker and $\mathrm{pH}$ adjusted to 2.20 using $1 \mathrm{M}$ sodium hydroxide solution. The solution was quantitatively transferred into a $100 \mathrm{~mL}$ volumetric flask, $0.5 \mathrm{~mL}$ of internal standard norleucine $(50 \mu \mathrm{mol} / \mathrm{mL})$ was added and made up to the mark with sodium citrate buffer $(c=0.2 \mathrm{~mol} / \mathrm{L}$, $\mathrm{pH} 2.20$ ). The extract was filtered in vials through $0.2 \mu \mathrm{m}$ membrane filters PTFE (Whatman, Clifton, NJ, USA).

\subsubsection{POST-COLUMN DERIVATIZATION AND CHROMATOGRAPHIC CONDITIONS}

Ion-exchange chromatography followed by postcolumn derivatization with ninhydrin was used (Spackman et al., 1958; Grunau and Swiader, 1992). Ninhydrin reacts with primary amino acids and hydrindantin to form Ruhemann's Purple which is detectable at $570 \mathrm{~nm}$. Ninhydrin reacts with secondary amino acids to form a yellow complex detectable at $440 \mathrm{~nm}$ (Ruhemann, 1910).

Agilent 1200 Series chromatograph with diode array detector (Agilent Technologies, Palo Alto, CA, USA) and post-column derivatization instrument Pinnacle PCX (Pickering Laboratories, Mountain View, CA, USA) were used for the separation of amino acids, their detection and quantification. The separation was performed at $48{ }^{\circ} \mathrm{C}$ using sodium cation exchange column $(8 \mu \mathrm{m}, 3.0 \mathrm{~mm} \times 250 \mathrm{~mm})$ with sodium guard column

Table 1: Gradient program for eluants Preglednica 1: Parametri gradientne elucije

\begin{tabular}{llcccc}
\hline Step & Time $(\mathrm{min})$ & Interval $(\mathrm{min})$ & $\begin{array}{l}\text { Sodium eluant } \\
\mathrm{pH} \mathrm{3.28} \mathrm{( \% )}\end{array}$ & $\begin{array}{l}\text { Sodium eluant } \\
\mathrm{pH} \mathrm{7.50} \mathrm{( \% )}\end{array}$ & $\begin{array}{l}\text { Sodium column } \\
\text { regenerant }(\%)\end{array}$ \\
\hline 0 & 0 & 0 & 100 & 0 & 0 \\
1 & 10 & 10 & 100 & 0 & 0 \\
2 & 32 & 22 & 0 & 100 & 0 \\
3 & 56 & 24 & 0 & 100 & 0 \\
4 & 56.1 & 0.1 & 0 & 0 & 100 \\
5 & 58 & 1.9 & 0 & 0 & 100 \\
6 & 58.1 & 0.1 & 100 & 0 & 0 \\
7 & 70 & 11.9 & 100 & 0 & 0 \\
\hline
\end{tabular}


(2.0 mm $\times 20 \mathrm{~mm}$, Pickering Laboratories, Mountain View, CA, USA). The ninhydrin reaction was carried out at $130{ }^{\circ} \mathrm{C}$ with a reactor volume of $500 \mu \mathrm{L}$ and flow rate $0.3 \mathrm{~mL} / \mathrm{min}$. The mobile phase consisted of sodium eluant $\mathrm{pH}$ 3.28, sodium eluant $\mathrm{pH} 7.50$ and sodium column regenerant (Pickering Laboratories, Mountain View, CA, USA). The gradient used is shown in Table 1. The column was equilibrated $10 \mathrm{~min}$ prior to the next analysis. The flow rate was $0.3 \mathrm{~mL} / \mathrm{min}$ and the injection volume was $10 \mu \mathrm{L}$. The wavelength for detection was at $570 \mathrm{~nm}$ for primary amino acids and at $440 \mathrm{~nm}$ for secondary amino acids.

\section{RESULTS AND DISCUSSION}

\subsection{METHOD VALIDATION}

\subsubsection{LINEARITY, LIMIT OF DETECTION, LIMIT OF QUANTIFICATION}

Linearity was verified by measuring the standard solutions of amino acids in five concentration levels for the calibration curve and five repetitions for each concentration level. Linearity and range were determined and cal- culated with $\mathrm{F}$ test and multiple linear regression. Calibration curves were linear in the ranges shown in Table 2 ( $\mathrm{R}^{2}$ from 0.9942 to 0.9998 ). For each amino acid limit of detection (LOD) and limit of quantification (LOQ) were calculated by using "least squares" method. LOD were from 2 to $5 \mathrm{mg} / 100 \mathrm{mg}$ of dry-cured ham and LOQ from 5 to $18 \mathrm{mg} / 100 \mathrm{mg}$ of dry-cured ham (Table 2).

\subsubsection{PRECISION, UNCERTAINTY AND RECOV- ERY}

Repeatability and reproducibility were determined within the period of 10 days; two samples of dry-cured ham were prepared each day (ISO 5725-2, 1994). Standard deviation of repeatability and standard deviation of reproducibility were calculated. Dispersion of results was checked with Cochran test and outliers with Grubbs test.

Uncertainty of repeatability and uncertainty of reproducibility were calculated by multiplying the standard deviation of repeatability and the standard deviation of reproducibility by Student's $t$ factor for 9 degrees of freedom and $95 \%$ confidence level $\left(t_{95 ; 9}=2.262\right)$. The results are given in Table 3 .

The recovery was checked on spiked samples in six

Table 2: Linearity, linear range, LOD and LOQ of the method for the determination of free amino acid content in dry-cured ham "Kraški pršut"

Preglednica 2: Linearnost, območje linearnosti, meje detekcije in meje kvantifikacije za metodo za določanje vsebnosti prostih amino kislin $v$ kraškem pršutu

\begin{tabular}{|c|c|c|c|c|}
\hline Amino acid & $\mathrm{R}^{2}$ & Lin. range (mg/100 g) & LOD (mg/100 g) & LOQ (mg/100 g) \\
\hline Aspartic acid & 0.9996 & $8-502$ & 2 & 8 \\
\hline Threonine & 0.9997 & $7-448$ & 2 & 7 \\
\hline Serine & 0.9998 & $5-397$ & 2 & 5 \\
\hline Glutamic acid & 0.9997 & $8-551$ & 2 & 8 \\
\hline Proline & 0.9994 & $18-608$ & 5 & 18 \\
\hline Glycine & 0.9997 & $5-284$ & 2 & 5 \\
\hline Alanine & 0.9995 & $5-335$ & 2 & 5 \\
\hline Cystine & 0.9997 & $16-901$ & 5 & 16 \\
\hline Valine & 0.9996 & $7-445$ & 2 & 7 \\
\hline Methionine & 0.9996 & $9-558$ & 3 & 9 \\
\hline Isoleucine & 0.9997 & $8-493$ & 2 & 8 \\
\hline Leucine & 0.9997 & $9-492$ & 3 & 9 \\
\hline Tyrosine & 0.9996 & $12-684$ & 4 & 12 \\
\hline Phenylalanine & 0.9997 & $11-620$ & 3 & 11 \\
\hline Lysine & 0.9942 & $6-549$ & 2 & 6 \\
\hline Histidine & 0.9988 & $7-235$ & 2 & 7 \\
\hline Arginine & 0.9998 & $9-659$ & 3 & 9 \\
\hline
\end{tabular}


Table 3: Standard deviations of repeatability (sr), repeatability limit (r), standard deviations of reproducibility (sR), reproducibility limit $(R)$, uncertainty of repeatability (Ur) and uncertainty of reproducibility (UR) of the method for the determination of free amino acid content in dry-cured ham "Kraški pršut" (in mg/100 g dry matter)

Preglednica 3: Standardni odkloni ponovljivosti (sr), meje ponovljivosti (r), standardni odkloni obnovljivosti (sR), meje obnovljivosti $(R)$, negotovost ponovljivosti (Ur) in negotovost obnovljivosti (UR) metode za določanje vsebnosti prostih amino kislin $v$ kraškem pršutu ( $v$ mg/100 g suhe snovi)

\begin{tabular}{|c|c|c|c|c|c|c|c|}
\hline Amino acid & Means of the levels & $\mathrm{s}_{r}$ & $\mathrm{r}$ & $\mathrm{s}_{R}$ & $\mathrm{R}$ & $\mathrm{U}_{r}$ & $\mathrm{U}_{R}$ \\
\hline Aspartic acid & 593 & 23 & 74 & 25 & 80 & 52 & 58 \\
\hline Threonine & 418 & 13 & 42 & 21 & 67 & 29 & 46 \\
\hline Serine & 523 & 13 & 42 & 27 & 86 & 30 & 61 \\
\hline Glutamic acid & 1153 & 26 & 83 & 47 & 150 & 58 & 106 \\
\hline Proline & 491 & 13 & 42 & 30 & 96 & 28 & 68 \\
\hline Glycine & 399 & 9 & 29 & 18 & 58 & 20 & 40 \\
\hline Alanine & 678 & 15 & 48 & 29 & 93 & 33 & 66 \\
\hline Cystine & 16 & 1 & 3 & 2 & 6 & 2 & 5 \\
\hline Valine & 593 & 16 & 51 & 28 & 90 & 37 & 63 \\
\hline Methionine & 271 & 8 & 26 & 12 & 38 & 18 & 28 \\
\hline Isoleucine & 464 & 12 & 38 & 25 & 80 & 27 & 56 \\
\hline Leucine & 693 & 16 & 51 & 33 & 106 & 37 & 75 \\
\hline Tyrosine & 281 & 7 & 22 & 15 & 48 & 17 & 35 \\
\hline Phenylalanine & 430 & 10 & 32 & 20 & 64 & 22 & 44 \\
\hline Lysine & 1074 & 22 & 70 & 46 & 147 & 50 & 103 \\
\hline Histidine & 275 & 6 & 19 & 15 & 48 & 13 & 34 \\
\hline Arginine & 525 & 12 & 38 & 22 & 70 & 27 & 49 \\
\hline
\end{tabular}

repetitions using the internal standard norleucine. The calculated recovery for norleucine was from $95.0 \%$ to 97.2\%.

\subsection{ANALYSIS OF DRY-CURED HAM SAMPLES}

Free amino acid content and chemical parameters were determined in 135 Slovenian dry-cured hams »Kraški pršut« for 2 different muscles. The results of chemical parameters are given in Table 4. In the SM muscle the moisture content and proteolysis index are lower in comparison with the BF muscle, but protein and total nitrogen content were observed to be higher. Higher quantity of total nitrogen can be explained by the difference in dry matter and moisture content. However, the

Table 4: Chemical parameters for the BF and SM muscle in dry-cured hams "Kraški pršut" (mean \pm standard deviation) Preglednica 4: Kemijski parametri za mišici BF in SM v kraškem pršutu (povprečje \pm standardni odklon)

\begin{tabular}{lcccc}
\hline Parameter & BF muscle & min-max & SM muscle & min-max \\
\hline Moisture (\%) & $58.5 \pm 1.5$ & $54.5-65.2$ & $49.0 \pm 2.3$ & $43.5-56.2$ \\
$\mathrm{NaCl}(\%)$ & $7.6 \pm 0.7$ & $5.9-9.4$ & $6.7 \pm 0.7$ & $4.5-8.3$ \\
Protein (\%) & $29.5 \pm 1.2$ & $26.0-33.6$ & $39.0 \pm 2.3$ & $32.0-43.9$ \\
Total nitrogen (g/kg) & $47.2 \pm 1.9$ & $41.6-54.0$ & $62.4 \pm 3.6$ & $51.2-70.2$ \\
Non-protein nitrogen (g/kg) & $12.6 \pm 1.0$ & $7.0-14.7$ & $11.8 \pm 1.1$ & $7.8-14.4$ \\
Proteolysis index (\%) & $26.8 \pm 1.8$ & $16.1-31.1$ & $18.9 \pm 1.8$ & $13.3-24.1$ \\
Intramuscular fat (\%) & $3.0 \pm 0.9$ & $1.6-6.2$ & $4.5 \pm 1.2$ & $2.1-8.8$ \\
Dry matter (g/kg) & $415 \pm 14$ & $377-455$ & $510 \pm 23$ & $438-565$ \\
\hline
\end{tabular}


concentration of salt is higher in the BF muscle. According to the literature, this can be explained by the fact that salt consequently moves to the areas with higher moisture content where more salt can be dissolved (Arnau et al., 1995; Monin et al., 1997). Higher proteolysis index and non-protein nitrogen contents were observed in the $\mathrm{BF}$ muscle. As this is an internal muscle, it is reached by the salt penetration much later and the desiccation is smaller than in the SM muscle (Arnau et al., 1995). Both factors, the salt content and the water availability, are crucial for the activity of muscle proteolytic enzymes and consequently the generation of non-protein nitrogen (Toldrá, 2002).

Table 5 shows the contents of free amino acids in dry-cured hams "Kraški pršut" for the BF and SM muscles. The amino acid content in "Kraški pršut" is in the middle of the range of values reported for other sorts of dry-cured hams (Toldrá and Flores, 1998). Considering the results calculated on dry matter basis, the content of free amino acids is higher in the BF muscle, which is in accordance with the result for the proteolysis index, also found to be higher in the BF muscle in the present ex- periment as well as in other reports (Monin et al., 1997; Čandek-Potokar et al., 2002). The exceptions were only the content of cystine (lower in the BF muscle) and the content of methionine and phenylalanine (lower in the SM muscle, though not statistically significant). Regarding the differences in the dry-cured ham procedures (length, temperature conditions, amount of salt added, raw materials) between the manufacturers and countries of origin, it is difficult to compare our results obtained for free amino acid content with the available literature data.

\section{CONCLUSION}

Chemical profile of dry-cured ham selected and processed in accordance with the Slovenian consortium rules for »Kraški pršut « was characterized and differences between the BF and SM muscle were investigated.

For the determination of free amino acids in drycured hams we used the method for the determination of free amino acids in animal feeding stuffs and modified the sample preparation. Validation of the method

Table 5: The free amino acid content (in mg/100 g dry matter) in dry-cured hams "Kraški pršut" for the BF and SM muscle (mean \pm standard deviation)

Preglednica 5: Vsebnost prostih amino kislin (v mg/100 g suhe snovi) v kraškem pršutu za mišici BF in SM (povprečje \pm standardni odklon)

\begin{tabular}{|c|c|c|c|c|c|}
\hline Amino acid & BF muscle & $\min -\max$ & SB muscle & $\min -\max$ & Sign. \\
\hline Aspartic acid & $450 \pm 19$ & $318-591$ & $391 \pm 17$ & $301-529$ & $* * *$ \\
\hline Threonine & $350 \pm 17$ & $273-441$ & $297 \pm 15$ & $214-412$ & $* * *$ \\
\hline Serine & $447 \pm 23$ & $332-593$ & $379 \pm 20$ & $327-557$ & $* * *$ \\
\hline Glutamic acid & $1007 \pm 40$ & $834-1213$ & $849 \pm 34$ & $666-1090$ & $* * *$ \\
\hline Proline & $446 \pm 27$ & $348-578$ & $370 \pm 22$ & $300-566$ & $* * *$ \\
\hline Glycine & $345 \pm 16$ & $268-431$ & $290 \pm 13$ & $218-388$ & $* * *$ \\
\hline Alanine & $622 \pm 27$ & $472-789$ & $519 \pm 23$ & $393-673$ & $* * *$ \\
\hline Cystine & $33 \pm 5$ & $4-80$ & $46 \pm 7$ & $6-130$ & $* * *$ \\
\hline Valine & $523 \pm 24$ & $406-655$ & $470 \pm 22$ & $363-660$ & $* * *$ \\
\hline Methionine & $215 \pm 9$ & $145-296$ & $211 \pm 9$ & $143-367$ & n.s. \\
\hline Isoleucine & $385 \pm 21$ & $280-524$ & $361 \pm 20$ & $252-598$ & $* * *$ \\
\hline Leucine & $566 \pm 26$ & $431-758$ & $529 \pm 24$ & $383-849$ & $* * *$ \\
\hline Tyrosine & $293 \pm 17$ & $218-381$ & $279 \pm 16$ & 209-398 & $* * *$ \\
\hline Phenylalanine & $342 \pm 16$ & $253-475$ & $341 \pm 16$ & $235-578$ & n.s. \\
\hline Lysine & $907 \pm 39$ & $723-1139$ & $789 \pm 34$ & $632-1076$ & $* * *$ \\
\hline Histidine & $234 \pm 14$ & $184-288$ & $213 \pm 12$ & $173-300$ & $* * *$ \\
\hline Arginine & $445 \pm 17$ & $249-593$ & $338 \pm 13$ & $200-530$ & $* * *$ \\
\hline Total & 7610 & & 6670 & & $* * *$ \\
\hline
\end{tabular}

Fisher test value Sign., significance level: ${ }^{* *}, \mathrm{P}<0.001$; ${ }^{* *}, \mathrm{P}<0.01$;, $\mathrm{P}<0.05 ;$ n.s., non significant 
has shown good repeatability, reproducibility and linearity. According to the validation parameters the method is appropriate for the determination of free amino acid content in dry-cured ham.

From the results obtained in the present work it can be concluded that the proteolysis index, the content of moisture, salt, non-protein nitrogen, and free amino acids are higher in the BF muscle compared to the SM muscle. The results concerning the free amino acid content reflect the chemical composition of dry-cured ham and the differences between both investigated muscles.

\section{ACKNOWLEDGEMENTS}

The research was funded by the grants of the research project TRUEFOOD ("Traditional United Europe Food"), an Integrated Project financed by the European Commission under the 6th Framework Programme for RTD, contract no. FOOD-CT-2006-016264. In Slovenia this study was also partly made with the grants of Slovenian Research Agency for the applied project L4-9468. The authors would also like to express their thanks to industrial partners taking part in this study Farme Ihan d.d., Turolense Ganadera S.A. (pig producers), KRAS d.d. and MIP d.d., Grupo Monte Nevado (dry ham processors), Agroalimentaria Teruel (abattoir) and Pyragena France (dry ham processor). The authors also thank Zvonko Bregar for his contribution to the present article.

\section{REFERENCES}

Arnau J., Guerrero, L., Casademont, G., Gou, P. 1995. Physical and chemical changes in different zones of normal and PSE dry cured ham during processing. Food Chem., 52: 63-69

Čandek-Potokar M., Monin G., Zlender B. 2002. Pork quality, processing, and sensory characteristics of dry-cured hams as influenced by Duroc crossing and sex. J. Anim. Sci., 80: 988-996

Gaull G.E. 1989. Taurine in pediatric nutrition: review and update. Pediatrics, 83: 433

Goll D.E., Thompson V.F., Li H., Wei W., Cong J. 2003. The Calpain System. Physiol. Rev., 83: 731-801

Grunau J.A., Swiader J.M. 1992. Chromatography of 99 amino acids and other ninhydrin-reactive compounds in the Pickering lithium gradient system. J. Chrom. A, 594: 165-171

ISO 13903. Animal feeding stuffs - Determination of amino acids content. International Organization for Standardization. 2005

ISO 1443. Meat and meat products - Determination of total fat content. International Organization for Standardization. 1973

ISO 5725-2. Accuracy (trueness and precision) of measurement methods and results - Part 2: Basic method for the determination of repeatability and reproducibility of a standard measurement method. International Organization for Standardization. 1994

ISO 5983-2. Animal feeding stuffs - Determination of nitrogen content and calculation of crude protein content - Part 2: Block digestion/steam distillation method. International Organization for Standardization. 2005

ISO 6496. Animal feeding stuffs - Determination of moisture and other volatile matter content. International Organization for Standardization. 1999

Kato, H., Rhue, M.R., Nishimura, T. 1989. Role of free amino acids and peptides in food taste. In: Flavor Chemistry. Teranishi R., Buttery R.G., Shahidi F. (eds.). Washington DC, American Chemical Society: 158-174

MacLeod G. 1986. The scientific and technological basis of meat flavours. In: Developments in Food Flavors. Birch G.G., Lindley M.G. (eds.). London, Elsevier: 191-223

McCain G.R., Blumer T.N., Craig H.B., Steel R.G. 1968. Free amino acids in ham muscle during successive aging periods and their relation to flavor. J. Food Sci., 33: 142-146

McDonald J.K., Barrett A.J. 1986. Pyroglutamyl peptidase I. In: Mammalian Proteases: A Glossary and Bibliography. McDonald J.K., Barrett A.J. (eds.). New York, Academic Press: 305-307

Molnár-Perl I. 2003. Quantitation of amino acids and amines in the same matrix by high-performance liquid chromatography, either simultaneously or separately. J. Chrom. A, 987: 291-309

Monin G., Marinova P., Talmant A., Martin J.F., Cornet M., Lanore D., Grasso F. 1997. Chemical and structural changes in dry-cured hams (Bayonne hams) during processing and effects of the dehairing technique. Meat Sci., 47, 29-47

Rodríguez-Nuñez E., Aristoy M., Toldrá F. 1995. Peptide generation in the processing of dry-cured ham. Food Chem., 53: $187-190$

Ruhemann S. 1910. Cyclic Di- and Tri-ketones. J. Chem. Soc., 97: 1438-1449

Škrlep M., Čandek-Potokar M., Kavar T., Žlender B., Hortós M., Gou P., Arnau J., Evans G., Southwood O., Diestre A., Robert N., Dutertre C., Santé-Lhoutellier V. 2010. Association of PRKAG3 and CAST genetic polymorphisms with traits of interest in dry-cured ham production: Comparative study in France, Slovenia and Spain. Livest. Sci., 128: 60-66

Spackman D.H., Stein W.H., Moore S. 1958. Automatic recording apparatus for use in chromatography of amino acids. Anal. Chem., 30: 1190-1206

Toldrá F. 2002. Dry-Cured Meat Products. Trumbull, CT, Food and Nutrition Press, Inc.: 244 p.

Toldrá F., Flores M. 1998. The role of muscle proteases and lipases in flavor development during the processing of drycured ham. Crit. Rev. Food Sci., 38, 4: 331-352 